\title{
Effect of Hyaluronic Acid and Poly-L-Lactic Acid Dermal Fillers on Collagen Synthesis: An in vitro and in vivo Study
}

This article was published in the following Dove Press journal: Clinical, Cosmetic and Investigational Dermatology

\section{Larissa Rocha Bertelli Cabral' \\ Lucas Novaes Teixeira (iD) Rodrigo Pinto Gimenez (D) ${ }^{2}$ Ana Paula Dias Demasi (iD Rui Barbosa de Brito Junior (D) Vera Cavalcanti de Araújo (iD) Elizabeth Ferreira Martinez (D) \\ 'Division of Cell Biology and Oral Pathology, Faculdade São Leopoldo Mandic, Campinas, São Paulo, Brazil; ${ }^{2}$ Division of Plastic Surgery, Faculdade São Leopoldo Mandic, Campinas, São Paulo, Brazil}

Correspondence: Elizabeth Ferreira Martinez

Division of Cell Biology and Oral Pathology, Faculdade São Leopoldo Mandic, Rua José Rocha Junqueira, 13, Campinas CEP 13045-755, São Paulo, Brazil

$\mathrm{Tel} / \mathrm{Fax}+551932113600$

Email dr.efmartinez@gmail.com
Purpose: Skin ageing is marked by structural and functional changes in epidermis and dermis, which result clinically in wrinkles, loss of elasticity, and rough-textured appearance. In this context, different dermal fillers have been used to overcome these negative effects associated with skin ageing, such as hyaluronic acid (HA) and poly-L-lactic acid (PLLA). Despite their low immunogenicity, these materials can cause an inflammatory reaction after application.

Materials and Methods: Considering high demand of HA and PLLA as filler material, this study aimed to evaluate their in vitro and in vivo effects. For the in vitro study, human dermal fibroblast cell cultures were supplemented with HA or PLLA for 24,48 , and $72 \mathrm{~h}$. The following parameters were assayed: 1) cell proliferation, 2) cell viability, and 3) quantification of type I collagen by ELISA. For the in vivo study, HA or PLLA was injected in the dermis of Wistar rats and the tissues were collected after 15, 30, and 60 days for histologic evaluation and for quantification of type I collagen by Western blotting. The quantitative data were statistically analyzed using an ANOVA two-way. The significance level was set at 5\%.

Results: At 72 h, high cell proliferation was observed for HA compared to control $(p<0.05)$. Cultures exposed to PLLA exhibited a reduction in both cell proliferation and viability compared to control in all time points $(\mathrm{p}<0.05)$. Type I collagen expression was greater in cultures exposed to HA or PLLA compared to control $(\mathrm{p}<0.05)$. Histologic analysis showed the presence of multinucleated cells only in the PLLA group in all experimental time points. Western blotting analysis revealed high content of type I collagen in HA compared to PLLA $(\mathrm{p}<0.05)$.

Conclusion: The present study addresses a potentially unfavorable effect of dermal PLLA filler on the fibroblast phenotype, with possible clinical complications, unlike HA.

Keywords: cell culture, extracellular matrix, ageing, skin

\section{Introduction}

Skin aging is a dynamic process that involves clinical and biological phenomena. The first comprises an intrinsic aging, which is similar to all internal organs. The second is extrinsic aging (photoaging), which occurs due to as consequence of external factors, chiefly ultraviolet (UV) irradiation. ${ }^{1}$

The structural integrity of all the dermis is reduced by a range of intrinsic and extrinsic factors resulting into enzymatic degradation of the collagen by metalloproteinases and, consequently, the fibroblasts' death.,

This process leads to results that can be observed clinically, such as wrinkles, atrophy, elastosis, dyschromic manifestations and volume loss. ${ }^{3,4}$ Therefore, in 
terms of the aging process, it would be inadvisable to correct a defect permanently at a precise time; instead, the best approach is to apply fillers as needed, to deal with the aging signs as they appear. ${ }^{5}$

The demand for injectable fillers continues to increase, ${ }^{6}$ and new fillers have been developed just recently, whose safety and efficacy are supported by research. ${ }^{7}$ There are many types of ideal fillers currently used by cosmetic and medical indication, in routine clinical practice. They can be classified as temporary, semi-permanent or permanent, and according to product composition. Primary ingredients include collagen, hyaluronic acid (HA), poly-L-lactic acid (PLLA), calcium hydroxyapatite and polymethyl methacrylate. ${ }^{5}$

HA is a glycosaminoglycan and a natural compound of the extracellular matrix. ${ }^{8}$ It can affect cell behavior and metabolism, ${ }^{9}$ and increases skin hydration and fibroblast proliferation by activating fibroblasts to express type I (Col-1) collagen and matrix metalloproteinase-1 (MMP1). In addition, HA modifies the organization of the actin cytoskeleton, influencing fibroblast shape and orientation. ${ }^{9}$

PLLA is a biocompatible, biodegradable, immunologically inert synthetic polymer that stimulates collagen synthesis, leading to gradual volume reestablishment. As the PLLA microparticles degrade, the inflammatory reaction responsible for the degradation of the particles promotes the formation of fibrous connective tissue and neocollagenesis, leading to gradual volume replacement. ${ }^{3,4,7,10}$ In addition, PLLA increases fibroblast activity and stimulates collagen synthesis. The result is not the effect of the product, but of the host's response to this process. ${ }^{6}$

However, the molecular and cellular processes underpinning these procedures are still elusive. ${ }^{11}$ This study aimed to evaluate in vitro cell viability, proliferation and type I collagen expression, using human dermal fibroblasts after HA (Juvederm Volbella ${ }^{\circledR}$, Irvine, CA, USA) and PLLA (Sculptra ${ }^{\circledR}$, Berwyn, PA, USA) supplementation. In addition, the histological aspects and type I collagen expression were investigated in vivo in an animal model.

\section{Materials and Methods}

This study was divided into two parts. The first one referred to the in vitro study, which is the main objective was to evaluate the effects of HA and PLLA on human dermal fibroblast cell cultures in terms of cell proliferation, cell viability, and type I collagen secretion. The second one referred to the in vivo study, which aimed to assay qualitatively the histologic aspects of dermis after HA and PLLA application in terms of biomaterials distribution among the collagen fibers and the presence of inflammatory cells as well as the quantification of type I collagen.

\section{In vitro Study}

\section{Cell Culture}

Human dermal fibroblast cells were obtained from explants of mammoplasty and abdominoplasty provided by three separate female donors (age range 42-57 years old), according to the methods previously described by Huschtscha et al. ${ }^{12}$ The samples were used after previous inform consent by the volunteers and approval by the Ethics Committee of the São Leopoldo Mandic Research Institute, Campinas, Brazil (\#2011/0143).

The fibroblast cell phenotype was confirmed by immunofluorescence for the anti- $\alpha$ smooth muscle actin, antitype I collagen, and anti-vimentin antibodies, which were positive, and by negativity for the pan-cytokeratin cocktail (AE1/AE3 antibody) (Figure 1).

The cells were cultured in Dulbecco's Modified Eagle's Medium (DMEM) (Sigma, St. Louis, MO, USA) supplemented with 10\% fetal bovine serum (DCS; GIBCO, Buffalo, NY) and $1 \%$ antimycotic-antibiotic solution (Sigma), and maintained at $37 \%$ in humid atmosphere containing $5 \% \mathrm{CO}_{2} \cdot{ }^{13}$ For all experimental assays, the cells were used at subculture levels 3 or 4 .

\section{Cell Proliferation and Viability Assays}

The influence of dermal fillers on human dermal fibroblasts was evaluated according to proliferation and viability assays, and type I collagen expression. The cells were grown in 24 and 96 wells plates (Corning, NY, USA) at an initial density of 110 cells $/ \mathrm{mm}^{2}$ per well. After $24 \mathrm{~h}$, the medium was changed, and left either unsupplemented or supplemented (C, control) with 0.5, 1.0, 5.0 and $10.0 \mathrm{mg} /$ $\mathrm{mL}^{14}$ of HA (Juvederm Volbella ${ }^{\circledR}$, Irvine, CA, USA), or $0.05,0.1,0.5$ and $1 \mathrm{mg} / \mathrm{mL}^{15}$ of PLLA (Sculptra ${ }^{\circledR}$, Berwyn, PA, USA). After 24, 48, and $72 \mathrm{~h}$, the cells were detached using $0.05 \%$ trypsin and counted using a hemocytometer to calculate proliferation indices. Using a different set of plates, with the same conditions as previously described, cell viability was determined by MTT assay, as described previously, at a wavelength of $590 \mathrm{~nm}$. The experiments were performed twice under the same conditions to ensure accuracy. 

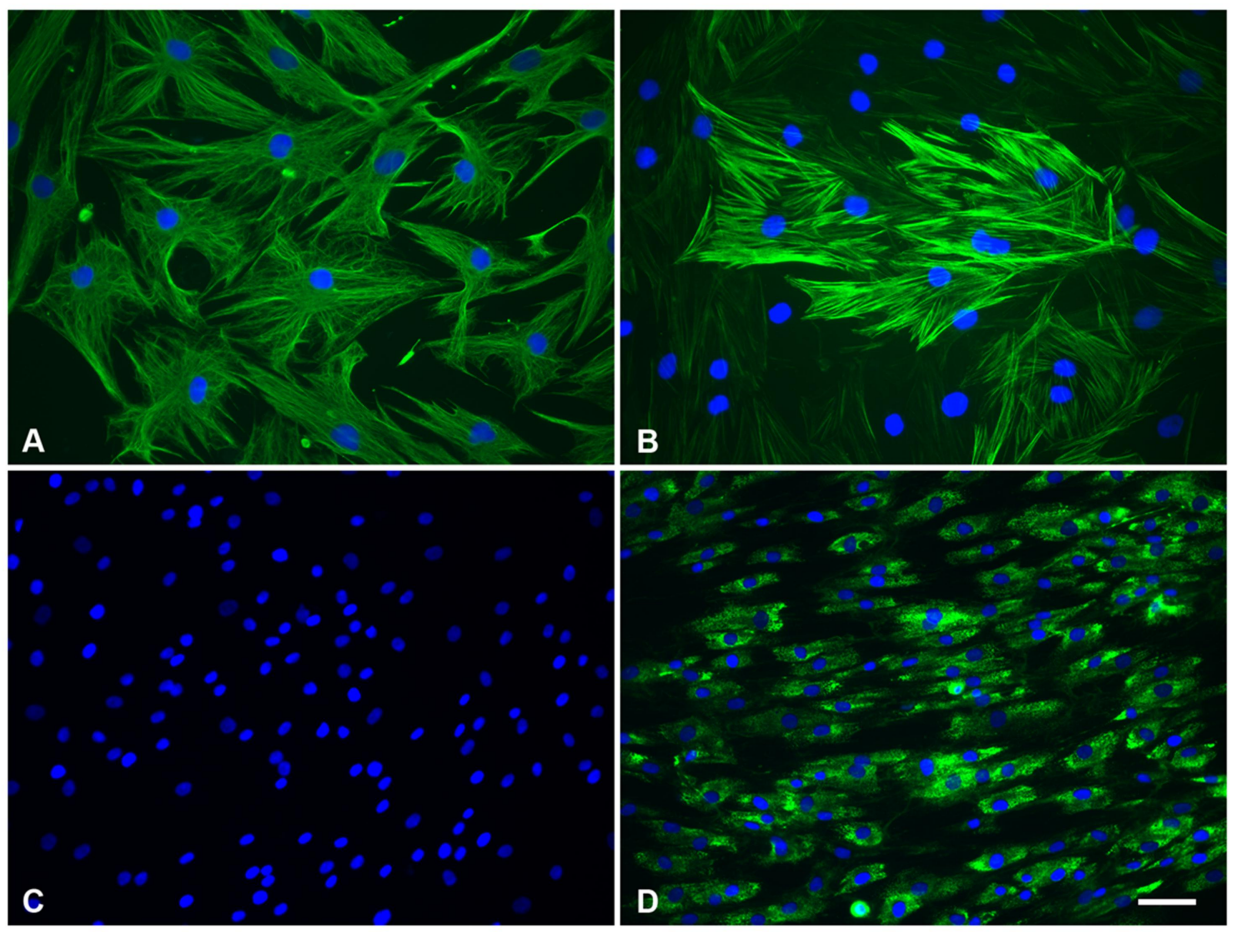

Figure I (A) Immunolocalization of vimentin, (B) $\alpha$-smooth muscle actin, (C) AEI/AE3, and (D) type I collagen (green, AlexaFluor 488) in seeded dermal fibroblast cells. DNA staining (DAPI, blue). Scale bar: $(\mathbf{A}$ and $\mathbf{B})=100 \mu \mathrm{m} ;(\mathbf{C}$ and $\mathbf{D})=50 \mu \mathrm{m}$.

\section{Type I Collagen Quantification by ELISA}

After 24, 48 and $72 \mathrm{~h}$, the supernatants from the cell cultures were harvested and centrifuged at $5000 \mathrm{~g}$ for 15 $\min$ at $4^{\circ} \mathrm{C}$. Aliquots of each sample were assayed by means of ELISA to determine the type I collagen levels, according to the manufacturer's recommendations (R\&D Systems, USA). Total type I collagen was quantitated in picograms per $\mathrm{mL}(\mathrm{pg} / \mathrm{mL})$. The results were calculated using the standard curves created in each assay. The ELISA assays were performed in a blind fashion in triplicate.

\section{In vivo Study \\ Specimen Preparation}

Male Wistar rats (250-350 g) were obtained from CEMIB UNICAMP (Centro de Bioterismo, State University of Campinas, SP) and were given chow and water ad libitum throughout the study. The experiments were approved by the Institutional Committee for Ethics in Animal Research of UNICAMP (\# 2015/005), and followed the recommendations of the Guide for the Care and Use of Laboratory Animals (AAALAC). Sculptra ${ }^{\circledR}$ dermal filler was reconstituted prior to use by the addition of $10 \mathrm{~mL}$ of sterile water for injection, as recommended by the manufacturer, resulting in a final concentration of $15 \mathrm{mg} / \mathrm{mL}$ of polyL-lactic acid. Juvederm Volbella ${ }^{\circledR}$ filler is ready for use and presents a $15 \mathrm{mg} / \mathrm{mL}$ of hyaluronic acid concentration. The animals were treated with $20 \mu \mathrm{L}$ dermal injection of the following treatment options: HA (Juvederm Volbella ${ }^{\circledR}$, Irvine, USA), PLLA (Sculptra ${ }^{\circledR}$, Berwyn, USA), PBS (control for $\mathrm{HA}, \mathrm{C}_{\mathrm{HA}}$ ), or distilled sterile water (control for PLLA, $\left.\mathrm{C}_{\text {PLLA }}\right)$. All the rats were anesthetized with $4 \%$ isoflurane, and kept on $2.5 \%$ isoflurane and $2 \mathrm{~L} /$ min oxygen anesthesia. Fifteen rats were treated with different treatments or left untreated on each side, resulting in five animals for each treatment at each time point (15, 30 and 60 days). Each injection was administered on the right or left flank using a 27-gauge needle (Exel International Medical Products, Los Angeles, CA, USA) and a linear threading technique. ${ }^{16}$ Euthanasia was performed by deepening anesthesia according to the following protocol: 90 to $150 \mathrm{mg} / \mathrm{kg}$ of sodium thiopental (71-73-8) combined with $10 \mathrm{mg} / \mathrm{mL}$ of Lidocaine (137-58-6), intraperitoneally. Full-thickness skin biopsy specimens were collected from the sites using a $11-\mathrm{mm}$ tissue scalpel (Sklar Instruments, West Chester, PA, USA), immediately after the euthanasia, at 15, 30 and 60 days. The biopsy specimens were collected and divided to perform the histological examination and Western blotting assay. 


\section{Histological Analysis}

A dorsal skin biopsy was obtained from each rat and fixed in $10 \%$ neutral-buffered formalin. The dorsal skin was shaved with an electric shaver before the skin samples were collected. A total of $4 \mu \mathrm{m}$ paraffin sections parallel to the longitudinal axis of the body were stained with hematoxylin and eosin (HE), and mounted on glass slides with biological resin (Permount, Fisher Scientific, Pittsburgh, PA, USA). The histological analysis consisted of assaying qualitatively the distribution of the filler biomaterials among the collagen fibers as well as the presence of inflammatory cells.

\section{Type I Collagen Quantification by Western Blotting}

Skin biopsy specimens were pulverized using nitrogen, harvested and homogenized in lysis buffer (50 mM, TrisHCL pH 7.5, 150 mM NaCl, 1\% NP-40, 0.5\% deoxycholate, $0.1 \%$ SDS) containing protease inhibitors. The Western blotting was carried out as described previously. ${ }^{13}$ The primary polyclonal antibody used was anti-type I collagen antibody (1:1000, Abcam, La Jolla, CA, USA). GAPDH primary polyclonal antibody was used as an endogenous control (1:1000; Santa Cruz Biotechnology). A goat anti-rabbit secondary antibody was used for $1 \mathrm{~h}$ (1:5000; Sigma). The reaction was revealed with chemiluminescent detection reagents (Pierce) and visualized using digital imaging equipment (ImageQuant LAS 4000, GE Healthcare). Optical density (OD) measurements were performed with NIH ImageJ 1.37 (National Institutes of Health, Bethesda, MD) to analyze the scanned membranes. Data are presented as total protein expression normalized to GAPDH. For accuracy, the experiments were performed twice, in the same conditions, for each sample.

\section{Statistical Analysis}

The data were first analyzed for normality, using the Shapiro-Wilk test. Two-way analysis of variance (ANOVA) with post hoc Bonferroni test was applied to all assays performed, at a significance level of $5 \%$. The results were expressed as the mean \pm standard deviation.

\section{Results}

\section{In vitro Study}

\section{Cell Proliferation and Viability Assay}

At 24 and $48 \mathrm{~h}$, cell proliferation and cell viability were similar among dermal fibroblast cells exposed to different concentrations of HA and the control group (ANOVA Two-Way, $\mathrm{p}>0.05$ ). At $72 \mathrm{~h}$, cell proliferation was similar among dermal fibroblast cells exposed to different concentrations of HA (ANOVA Two-Way, $\mathrm{p}>0.05$ ), but superior to the control group (ANOVA Two-Way, $\mathrm{p}<0.05$ ). At $72 \mathrm{~h}$, the levels of cell viability were similar between the control group and dermal fibroblast cell cultures exposed to HA at $0.5 \mathrm{mg} / \mathrm{mL}$ (ANOVA Two-Way, $\mathrm{p}>0.05$ ) and greater than those ones observed for dermal fibroblast cells exposed to $\mathrm{HA}$ at $1 \mathrm{mg} / \mathrm{mL}, 5 \mathrm{mg} / \mathrm{mL}$, and $10 \mathrm{mg} / \mathrm{mL}$ (ANOVA TwoWay $\mathrm{p}<0.05$ ) (Table 1).

At $24 \mathrm{~h}$, dermal fibroblast cells exposed to PLLA at $0.05 \mathrm{mg} / \mathrm{mL}$ and $0.5 \mathrm{mg} / \mathrm{mL}$ exhibited low proliferation rate compared with other experiment groups (ANOVA Two-Way, $\mathrm{p}<0.05$ ). At 48 and $72 \mathrm{~h}$, a significant reduction in cell proliferation was observed for dermal fibroblast cells exposed to different concentrations of PLLA in comparison with the control group (ANOVA Two-Way, $\mathrm{p}<0.05)$. At 24,48 , and $72 \mathrm{~h}$, the levels of cell viability were superior in control group compared to those ones observed for dermal fibroblast cells exposed to different concentrations of PLLA (ANOVA Two-Way, $\mathrm{p}<0.05$ ) (Table 2).

\section{Type I Collagen Quantification by ELISA}

ELISA analyses revealed that culture medium of dermal fibroblast exposed to HA or PLLA, irrespective of the

Table I Cell Proliferation (A) and Viability (B) of Fibroblast Cell Cultures After 24, 48 and $72 \mathrm{~h}$ of Treatment with Different Doses of HA $(0.5,1.0,5.0$ and $10 \mathrm{mg} / \mathrm{ml})$ Compared with the Control Group

\begin{tabular}{|c|c|c|c|}
\hline Group/Hours & 24 & 48 & 72 \\
\hline \multicolumn{4}{|l|}{ (A) } \\
\hline Control & $0.38 \pm 0.03^{\mathrm{A}, \mathrm{a}}$ & $0.52 \pm 0.04^{\mathrm{A}, \mathrm{b}}$ & $0.49 \pm 0.05^{\mathrm{A}, \mathrm{b}}$ \\
\hline $0.5 \mathrm{mg} / \mathrm{mL}$ & $0.33 \pm 0.07^{\mathrm{A}, \mathrm{a}}$ & $0.56 \pm 0.10^{\mathrm{A}, \mathrm{b}}$ & $0.61 \pm 0.06^{\mathrm{B}, \mathrm{b}}$ \\
\hline $\mathrm{I} \mathrm{mg} / \mathrm{mL}$ & $0.38 \pm 0.09^{\mathrm{A}, \mathrm{a}}$ & $0.60 \pm 0.09^{\mathrm{A}, \mathrm{b}}$ & $0.63 \pm 0.14^{\mathrm{B}, \mathrm{b}}$ \\
\hline $5 \mathrm{mg} / \mathrm{mL}$ & $0.4 I \pm 0.05^{\mathrm{A}, \mathrm{a}}$ & $0.53 \pm 0.07^{\mathrm{A}, \mathrm{b}}$ & $0.62 \pm 0.03^{\mathrm{B}, \mathrm{b}}$ \\
\hline $10 \mathrm{mg} / \mathrm{mL}$ & $0.42 \pm 0.07^{\mathrm{A}, \mathrm{a}}$ & $0.58 \pm 0.08^{\mathrm{A}, \mathrm{b}}$ & $0.65 \pm 0.05^{\mathrm{B}, \mathrm{b}}$ \\
\hline \multicolumn{4}{|l|}{ (B) } \\
\hline Control & $0.24 \pm 0.04^{\mathrm{A}, \mathrm{a}}$ & $0.32 \pm 0.09^{\mathrm{A}, \mathrm{b}}$ & $0.45 \pm 0.14^{\mathrm{A}, \mathrm{c}}$ \\
\hline $0.5 \mathrm{mg} / \mathrm{mL}$ & $0.29 \pm 0.07^{\mathrm{A}, \mathrm{a}}$ & $0.29 \pm 0.04^{\mathrm{A}, \mathrm{a}}$ & $0.47 \pm 0.13^{\mathrm{A}, \mathrm{b}}$ \\
\hline $\mathrm{l} \mathrm{mg} / \mathrm{mL}$ & $0.29 \pm 0.07^{\mathrm{A}, \mathrm{a}}$ & $0.32 \pm 0.07^{\mathrm{A}, \mathrm{a}}$ & $0.37 \pm 0.07^{\mathrm{B}, \mathrm{a}}$ \\
\hline $5 \mathrm{mg} / \mathrm{mL}$ & $0.26 \pm 0.06^{\mathrm{A}, \mathrm{a}}$ & $0.32 \pm 0.06^{\mathrm{A}, \mathrm{a}, \mathrm{b}}$ & $0.35 \pm 0.10^{\mathrm{B}, \mathrm{b}}$ \\
\hline $10 \mathrm{mg} / \mathrm{mL}$ & $0.23 \pm 0.02^{\mathrm{A}, \mathrm{a}}$ & $0.29 \pm 0.07^{\mathrm{A}, \mathrm{a}, \mathrm{b}}$ & $0.36 \pm 0.09^{\mathrm{B}, \mathrm{b}}$ \\
\hline
\end{tabular}

Notes: Different capital letters represent significant differences among groups, for each experimental time. Different lowercase letters indicate significant differences at different times. Cell proliferation was expressed as number of cells $\times 10^{4}$ and cell viability was expressed as arbitrary units $(A U)$. Data were reported as the mean $\pm S D$. 
Table 2 Cell Proliferation (A) and Viability (B) of Fibroblast Cell Cultures After 24, 48 and $72 \mathrm{~h}$ of Treatment with Different Doses of PLLA $(0.05,0.1,0.5$ and I mg/ml) Compared with the Control Group

\begin{tabular}{|l|l|l|l|}
\hline Group/Hours & 24 & 48 & 72 \\
\hline (A) & $0.47 \pm 0.04^{\mathrm{A}, \mathrm{C}, \mathrm{a}}$ & $0.61 \pm 0.07^{\mathrm{A}, \mathrm{b}}$ & $0.64 \pm 0.08^{\mathrm{A}, \mathrm{b}}$ \\
\hline Control & $0.26 \pm 0.05^{\mathrm{B}, \mathrm{a}}$ & $0.29 \pm 0.06^{\mathrm{B}, \mathrm{a}}$ & $0.30 \pm 0.07^{\mathrm{B}, \mathrm{a}}$ \\
$0.05 \mathrm{mg} / \mathrm{mL}$ & $0.40 \pm 0.05^{\mathrm{C}, \mathrm{D}, \mathrm{a}}$ & $0.49 \pm 0.05^{\mathrm{C}, \mathrm{b}}$ & $0.48 \pm 0.10^{\mathrm{C}, \mathrm{b}}$ \\
$0.1 \mathrm{mg} / \mathrm{mL}$ & $0.34 \pm 0.02^{\mathrm{D}, \mathrm{a}, \mathrm{c}}$ & $0.43 \pm 0.03^{\mathrm{C}, \mathrm{b}}$ & $0.40 \pm 0.05^{\mathrm{D}, \mathrm{b}, \mathrm{c}}$ \\
$0.5 \mathrm{mg} / \mathrm{mL}$ & $0.46 \pm 0.04^{\mathrm{C}, \mathrm{a}}$ & $0.48 \pm 0.05^{\mathrm{C}, \mathrm{a}}$ & $0.48 \pm 0.05^{\mathrm{C}, \mathrm{E}, \mathrm{a}}$ \\
I mg/mL & \multicolumn{4}{|l}{} \\
\hline \multicolumn{4}{|l}{} \\
(B) & $0.29 \pm 0.06^{\mathrm{A}, \mathrm{D}, \mathrm{a}}$ & $0.27 \pm 0.02^{\mathrm{A}, \mathrm{a}}$ & $0.40 \pm 0.05^{\mathrm{A}, \mathrm{b}}$ \\
\hline Control & $0.16 \pm 0.03^{\mathrm{B}, \mathrm{a}}$ & $0.15 \pm 0.04^{\mathrm{B}, \mathrm{a}}$ & $0.29 \pm 0.09^{\mathrm{B}, \mathrm{b}}$ \\
$0.05 \mathrm{mg} / \mathrm{mL}$ & $0.24 \pm 0.09^{\mathrm{C}, \mathrm{a}}$ & $0.17 \pm 0.07^{\mathrm{B}, \mathrm{b}}$ & $0.27 \pm 0.06^{\mathrm{B}, \mathrm{a}, \mathrm{c}}$ \\
$0.1 \mathrm{mg} / \mathrm{mL}$ & $0.23 \pm 0.05^{\mathrm{C}, \mathrm{a}}$ & $0.29 \pm 0.06^{\mathrm{A}, \mathrm{a}}$ & $0.28 \pm 0.08^{\mathrm{B}, \mathrm{a}}$ \\
$0.5 \mathrm{mg} / \mathrm{mL}$ & $0.32 \pm 0.06^{\mathrm{D}, \mathrm{a}}$ & $0.28 \pm 0.05^{\mathrm{A}, \mathrm{a}}$ & $0.31 \pm 0.09^{\mathrm{B}, \mathrm{a}}$ \\
\hline
\end{tabular}

Notes: Different lowercase letters indicate significant differences at different times. Cell proliferation was expressed as number of cells $\times 10^{4}$ and cell viability was expressed as arbitrary units (AU). Data were reported as the mean \pm SD.

Table 3 Quantification of Type I Collagen by Means of ELISA, After 24, 48 and $72 \mathrm{~h}$ of Treatment with Different Doses of HA (A) and PLLA (B) Compared with the Control Group

\begin{tabular}{|c|c|c|c|}
\hline Group/Hours & 24 & 48 & 72 \\
\hline \multicolumn{4}{|l|}{ (A) } \\
\hline Control & $15.59 \pm 0.46^{\mathrm{A}, \mathrm{a}}$ & $18.26 \pm 1.39^{\mathrm{A}, \mathrm{b}}$ & $16.16 \pm 2.89^{\mathrm{A}, \mathrm{a}}$ \\
\hline $0.5 \mathrm{mg} / \mathrm{mL}$ & $28.90 \pm 1.10^{\mathrm{B}, \mathrm{a}}$ & $26.86 \pm 1.08^{\mathrm{B}, \mathrm{a}}$ & $27.45 \pm 0.94^{\mathrm{B}, \mathrm{a}}$ \\
\hline $\mathrm{I} \mathrm{mg} / \mathrm{mL}$ & $27.76 \pm 1.13^{\mathrm{B}, \mathrm{a}}$ & $26.94 \pm 1.26^{\mathrm{B}, \mathrm{a}}$ & $25.02 \pm 1.19^{\mathrm{C}, \mathrm{a}}$ \\
\hline $5 \mathrm{mg} / \mathrm{mL}$ & $24.95 \pm 0.67^{\mathrm{C}, \mathrm{a}}$ & $27.22 \pm 0.44^{\mathrm{B}, \mathrm{b}}$ & $22.82 \pm 0.87^{\mathrm{D}, \mathrm{c}}$ \\
\hline $10 \mathrm{mg} / \mathrm{mL}$ & $24.24 \pm 0.86^{\mathrm{C}, \mathrm{a}}$ & $26.96 \pm 0.8 I^{\mathrm{B}, \mathrm{b}}$ & $21.53 \pm 1.60^{\mathrm{D}, \mathrm{c}}$ \\
\hline \multicolumn{4}{|l|}{ (B) } \\
\hline Control & $15.59 \pm 0.46^{\mathrm{A}, \mathrm{a}}$ & $18.26 \pm 1.39^{\mathrm{A}, \mathrm{a}}$ & $16.16 \pm 2.89^{\mathrm{A}, \mathrm{a}}$ \\
\hline $0.05 \mathrm{mg} / \mathrm{mL}$ & $21.09 \pm 1.86^{\mathrm{B}, \mathrm{a}}$ & $26.43 \pm I .28^{\mathrm{B}, \mathrm{b}}$ & $25.10 \pm 1.23^{\mathrm{B}, \mathrm{b}}$ \\
\hline $0.1 \mathrm{mg} / \mathrm{mL}$ & $21.51 \pm 1.37^{\mathrm{B}, \mathrm{a}}$ & $28.78 \pm \mathrm{I} .19^{\mathrm{B}, \mathrm{b}}$ & $28.34 \pm 1.16^{\mathrm{B}, \mathrm{b}}$ \\
\hline $0.5 \mathrm{mg} / \mathrm{mL}$ & $23.15 \pm 1.66^{\mathrm{B}, \mathrm{C}, \mathrm{a}}$ & $26.07 \pm 2.89^{\mathrm{B}, \mathrm{b}}$ & $27.73 \pm 2.55^{\mathrm{B}, \mathrm{b}}$ \\
\hline $\mathrm{I} \mathrm{mg} / \mathrm{mL}$ & $25.30 \pm 0.63^{C, D, a}$ & $29.64 \pm 1.20^{\mathrm{B}, \mathrm{b}, \mathrm{c}}$ & $27.44 \pm 0.75^{\mathrm{B}, \mathrm{a}, \mathrm{c}}$ \\
\hline
\end{tabular}

Notes: Different capital letters represent significant differences among groups, for each experimental time. Different lowercase letters indicate significant differences at different times. The results were expressed as $\mathrm{pg} / \mathrm{ml}$. Data were reported as the mean \pm SD.

concentration, exhibited high levels of type I collagen in comparison with the control group in all experimental points evaluated (ANOVA Two-Way, $\mathrm{p}<0.05$ ) (Table 3).

\section{In vivo Study}

Histological Analysis

Representative images of dermal skin biopsies after the respective treatments are shown in Figures 2-4. The presence of collagen fibers interspersed with hair follicle, sebaceous glands and blood vessels, characterizing normal dermis, was observed in both control groups $\left(\mathrm{C}_{\mathrm{HA}}\right.$ and $\mathrm{C}_{\text {PLLA }}$ ), and at all the experimental time points (Figures 2$4 \mathrm{~A}-\mathrm{D})$.

The highest HA concentration in the deep dermis (Figure 2E and F) occurred after 15 days in the HA group; however, the substance was found to be evenly distributed after 30 and 60 days (Figures 3 and 4E and F). No inflammatory process was observed at any of the time points evaluated.

In contrast, an intense inflammatory process was observed in the PLLA group, characterized by multinucleated cells, lymphocytes and macrophages, especially after 60 days. Degradation of the PLLA was observed over time, as identified by the increase in multinucleated giant cells and areas affected by phagocytosis (Figures 2-4G and H). Moreover, innumerous PLLA dermal filler crystals could be seen, especially after 60 days.

\section{Type I Collagen Quantification by Western Blotting}

Validation of the histological analysis was achieved by evaluating type I collagen protein content by immunoblotting (Figure 5). In all the experimental periods, higher type I collagen expression was observed when the dermal fillers were injected, as compared with the respective control groups $\left(\mathrm{C}_{\mathrm{HA}}\right.$ or $\left.\mathrm{C}_{\mathrm{PLLA}}\right)$. In both control groups, type I collagen content was found to be significantly lower than that of the respective dermal filler groups. At day 30 and 60 , the type I collagen expression was greater in HA group compared to PLLA group (ANOVA Two-Way, $\mathrm{p}<0.05)$.

\section{Discussion}

The search for non-invasive cosmetic procedures is an on-going activity in medicine. Currently, several dermal fillers considered safe for use are available. However, their indiscriminate use may result in more serious outcomes, and greater patient risk, depending on the individual's systemic conditions. ${ }^{17}$ Notably, dermal fillers are extensively used and have proven to be effective in improving appearance and repairing imperfections. ${ }^{4}$ Among several available substances, hyaluronic acid (HA) and poly-L-lactic acid (PLLA) have been widely used. However, few in vitro and in vivo studies back up their use, especially if their effectiveness in attenuating 


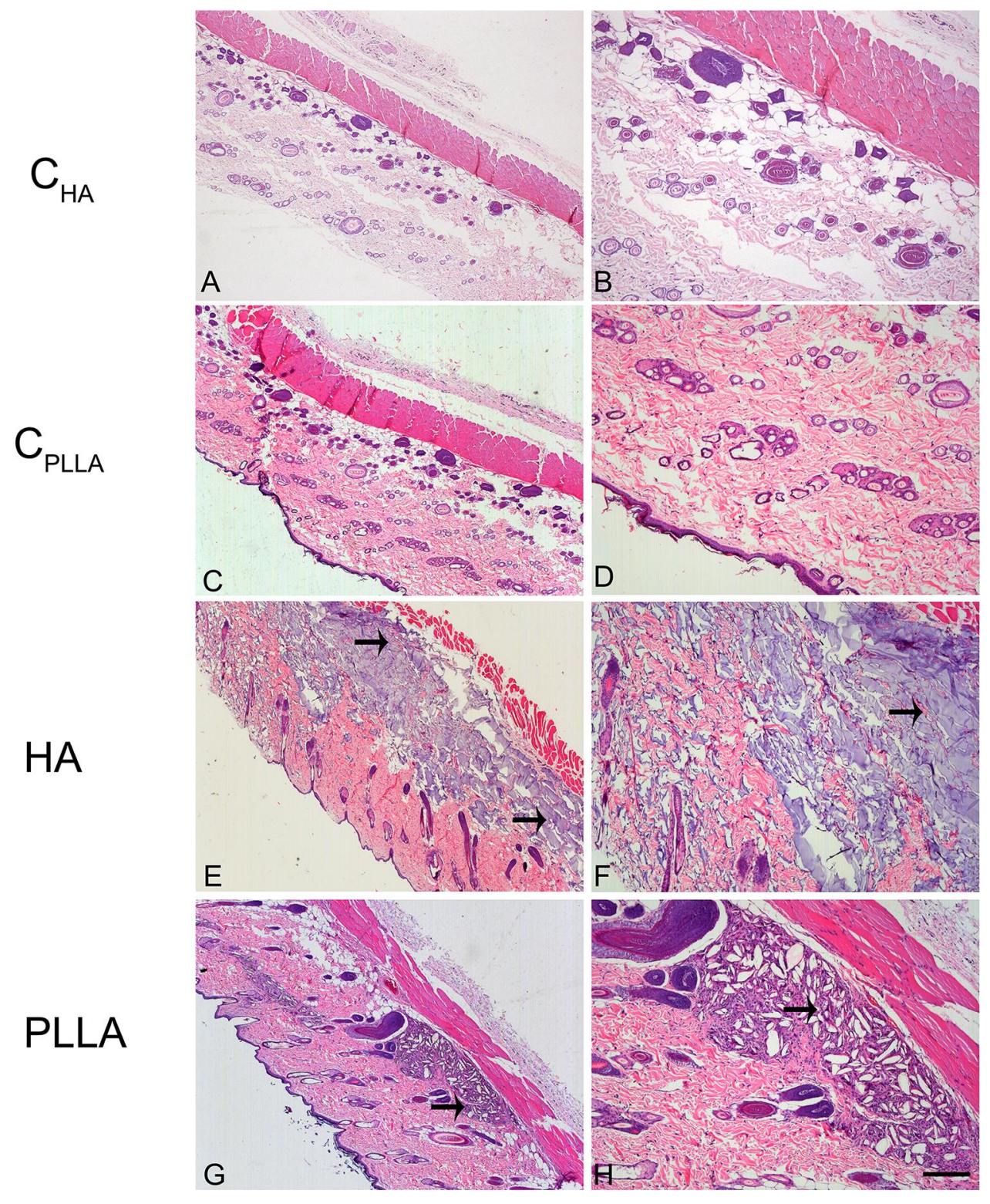

Figure 2 Photomicrograph of dermal skin biopsies after 15 days of dermal injection of PBS (control for HA: A and B), distilled water (control for PLLA: C and D), HA (E and $\mathbf{F}$ ), and PLLA (G and $\mathbf{H})$. Arrows indicate the presence of dermal filler. Scale: $(\mathbf{A}, \mathbf{C}, \mathbf{E}$ and $\mathbf{G})=500 \mu \mathrm{m} ;(\mathbf{B}, \mathbf{D}, \mathbf{F}$ and $\mathbf{H})=200 \mu \mathrm{m}$.

imperfections is based on filling action or stimulation of collagen production.

The results obtained in this study confirm the unfavorable effects of PLLA on skin fibroblasts in vitro, and extracellular matrix in vivo after its application. HA supplementation was found not only to promote fibroblast proliferation and viability, but also to increase type I collagen without causing apparent inflammation, compared with PLLA.

In fact, HA is the major component of the skin extracellular matrix, involved in regulating cell proliferation and migration, ${ }^{10}$ as well as promoting angiogenesis. ${ }^{15}$ As a natural skin component, HA has the advantages of not causing rejection, having low immunogenic action, and possessing viscoelastic and hygroscopic properties. $^{7}$ These characteristics promote increased skin hydration when HA is applied as a dermal filling, characterized by excellent mechanical properties and moderate durability. ${ }^{3}$ In fact, after 30 days of analysis, the present histological investigation showed that HA occasionally was sparsely distributed, and no inflammatory process was observed at any of the time points evaluated, thus emphasizing its favorable biological properties. In addition to inducing type I collagen formation, HA promoted an increase in 


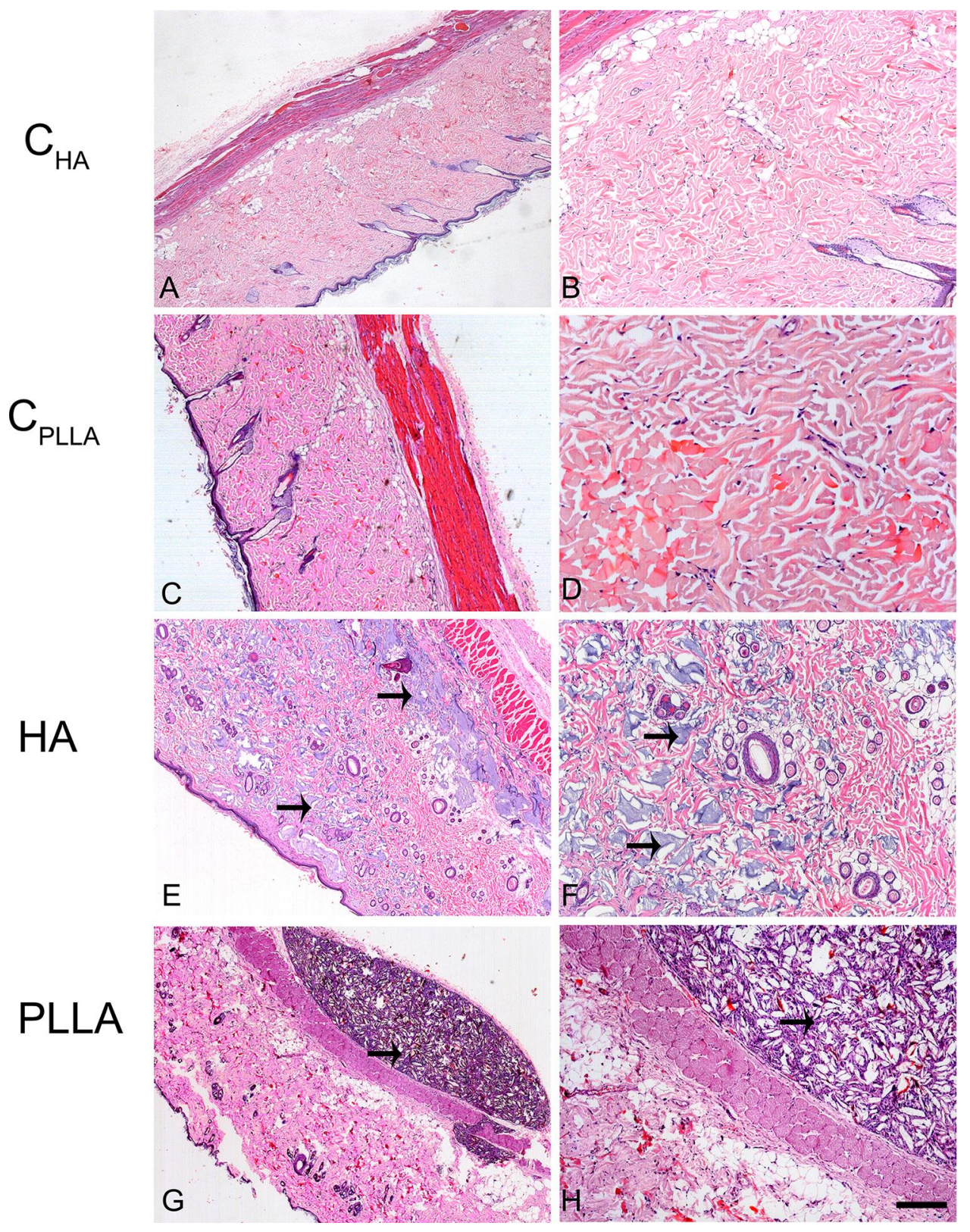

Figure 3 Photomicrograph of dermal skin biopsies after 30 days of dermal injection of PBS (control for HA: A and B), distilled water (control for PLLA: C and D), HA (E and $\mathbf{F}$ ), and PLLA ( $\mathbf{G}$ and $\mathbf{H})$. Arrows indicate the presence of dermal filler. Scale: $(\mathbf{A}, \mathbf{C}, \mathbf{E}$ and $\mathbf{G})=500 \mu \mathrm{m} ;(\mathbf{B}, \mathbf{D}, \mathbf{F}$ and $\mathbf{H})=200 \mu \mathrm{m}$.

cell proliferation, thus corroborating the findings by Rock et $\mathrm{al}^{16}$ after 7 days of cell culture.

These results are in line with those of previous studies, ${ }^{18-20}$ which suggest that exogenous HA affects fibroblast proliferation and collagen synthesis, by increasing their local volume predictably.

In contrast to the promising achievements of HA dermal filler, PLLA promotes an in vitro decrease in cell proliferation and viability, mainly observed after
$72 \mathrm{~h}$. PLLA is a synthetic, biocompatible and biodegradable polymer used in various areas of medicine. ${ }^{14,21,22}$ Results of the histological analysis of PLLA conducted in this study confirm that PLLA injection-induced local tissue reaction. An intense inflammatory process ensued from the reaction to a foreign body, represented by innumerous multinucleated cells, surrounded by a fibrous capsule. After 60 days, the presence of PLLA dermal filler was still evident, accompanied by stretching of the skin. 


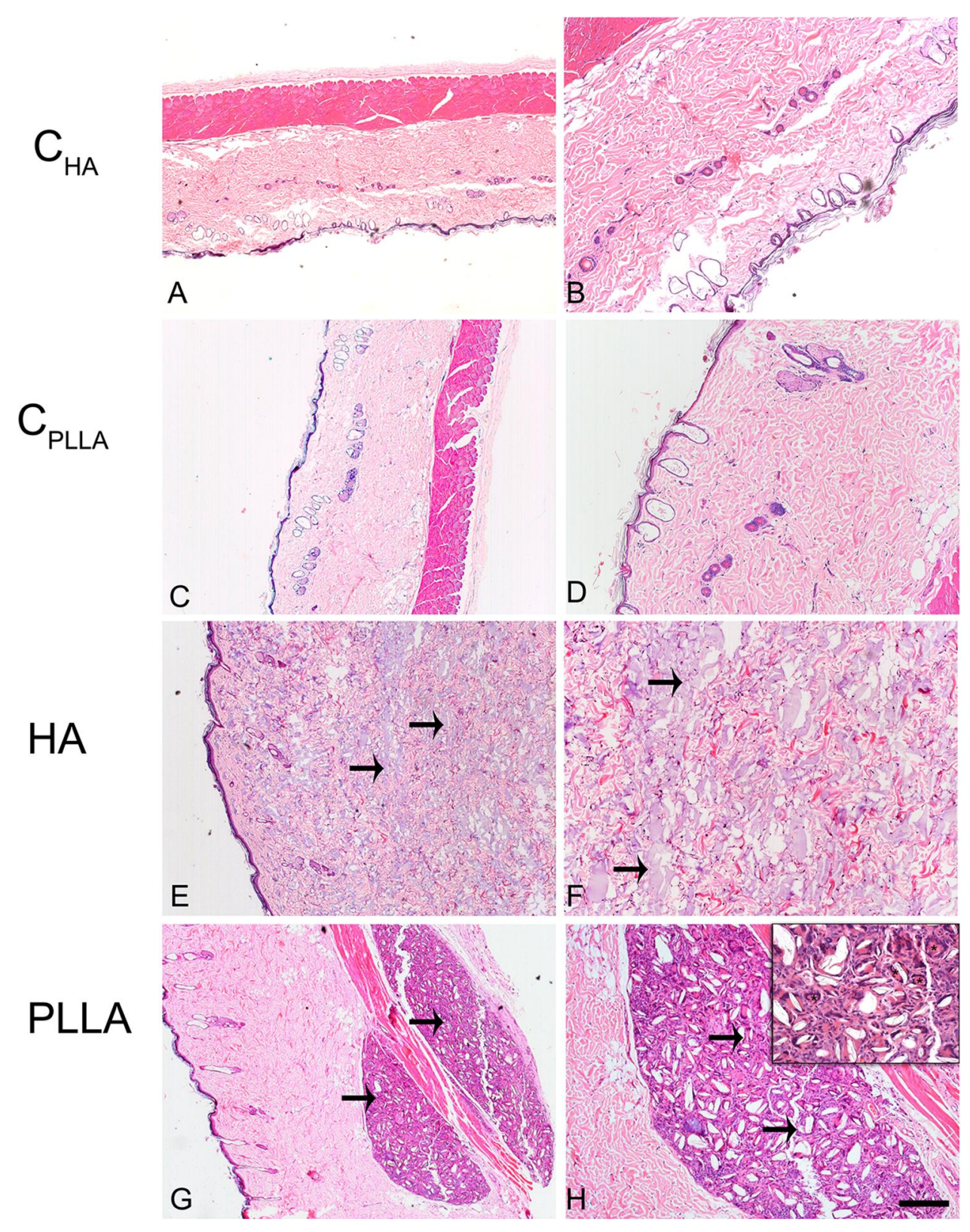

Figure 4 Photomicrograph of dermal skin biopsies after 60 days of dermal injection of PBS (control for HA: A and B), distilled water (control for PLLA: C and D), HA $(\mathbf{E}$ and $\mathbf{F})$, and PLLA ( $\mathbf{G}$ and $\mathbf{H})$. Arrows indicate the presence of dermal filler. The asterisks show multinucleated giant cells (inset). Scale: $(\mathbf{A}, \mathbf{C}, \mathbf{E}$ and $\mathbf{G})=500 \mu \mathrm{m} ;(\mathbf{B}, \mathbf{D}$, $\mathbf{F}$ and $\mathbf{H})=200 \mu \mathrm{m}$. Inset $=20 \mu \mathrm{m}$.

These findings reinforce the conclusion that dermal thickness in patients receiving PLLA dermal filler is brought about by local tissue reaction. As soon as the filler is applied, the tissue stretches mechanically, resulting from injection of the fluid and leading to increased edema caused by the fluid carrier. In time, macrophages slowly degrade PLLA into lactic acid microspheres resulting from lactate production, ${ }^{23}$ giving rise to many small crystals responsible for fibroblast stimulation and type I collagen production. ${ }^{8,24-26}$ Moreover, PLLA particles are flat pointed shape and did not dissolve in distilled water homogeneously. ${ }^{27}$ In this respect, the more short-lived effect of HA than PLLA can be observed clinically, thus requiring reapplications of $\mathrm{HA}$ to be made at shorter intervals than those of PLLA.

\section{Conclusion}

Based on the results of the present study, dermal PLLA filler was found to have a potentially unfavorable effect on the fibroblast phenotype, possibly causing clinical 


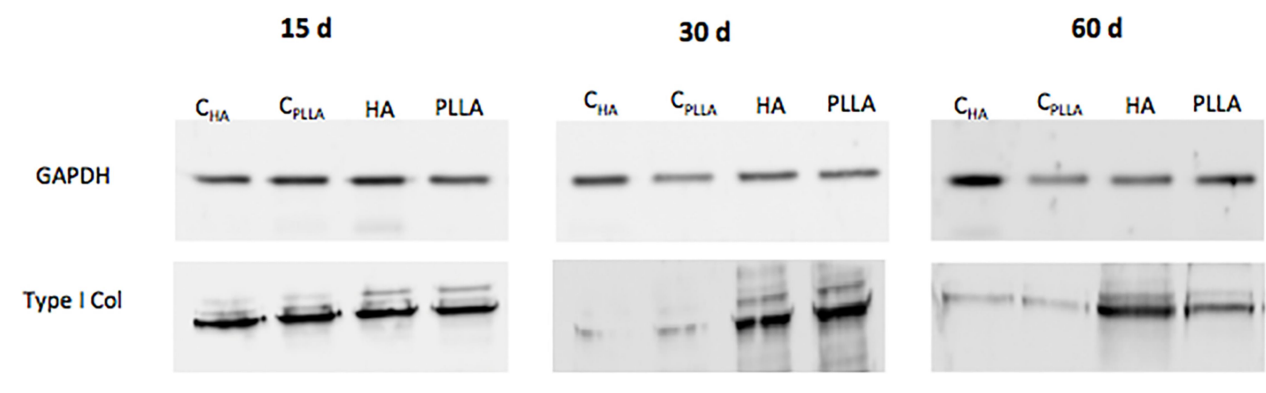

\begin{tabular}{|c|c|c|c|c|}
\hline days & $C_{H A}$ & $C_{\text {pluA }}$ & HA & PLLA \\
\hline 15 & $0.81 \pm 0.07^{A, a}$ & $0.79 \pm 0.09^{\wedge, a}$ & $0.89 \pm 0.22^{A, c}$ & $0.83 \pm 0.13^{A, b}$ \\
\hline 30 & $0.79 \pm 0.04 c$ & $0.77 \pm 0.03^{c, a}$ & $2.53 \pm 0.32^{c, a}$ & $1.25 \pm 0.11^{8, a}$ \\
\hline 60 & $0.62 \pm 0.05^{c}$ & $0.56 \pm 0.03^{C, a}$ & $1.38 \pm 0.24^{A b}$ & $0.85 \pm 0.09^{\mathrm{B}, \mathrm{b}}$ \\
\hline
\end{tabular}

Figure 5 Representative immunoblot of type I collagen expression on dermal skin after 15, 30 and 60 days of dermal filler treatment. Densitometric quantification (in arbitrary units, $\mathrm{AU}$ ) normalizing protein loading to GAPDH. Different uppercase letters represent significant differences among the groups at each experimental time point. Different lowercase letters indicate significant differences at different time points.

complications. In contrast, HA provides favorable effects on the fibroblast phenotype in vitro and in vivo, including higher cell proliferation and type I collagen synthesis.

\section{Acknowledgments}

The authors would like to thank Nadir Freitas and Pollyanna Montaldi for their technical support.

\section{Disclosure}

The authors have no conflict of interest to declare for this work.

\section{References}

1. Tzellos TG, Klagas I, Vahtsevanos K, et al. Extrinsic ageing in the human skin is associated with alterations in the expression of hyaluronic acid and its metabolizing enzymes. Exp Dermatol. 2009;18 (12):1028-1035. doi:10.1111/j.1600-0625.2009.00889.x

2. Courderot-Masuyer C, Robin S, Tauzin H, Humbert P. Evaluation of the behaviour of wrinkles fibroblasts and normal aged fibroblasts in the presence of Poly-L-Lactic acid. J Cosmet Dermatol Sci Appl. 2012;2 (1):20-27.

3. Sadick NS, Manhas-Bhutani S, Krueger N. A novel approach to structural facial volume replacement. Aesthetic Plast Surg. 2013;37 (2):266-276. doi:10.1007/s00266-012-0052-6

4. Johl SS, Burgett RA. Dermal filler agents: a practical review. Curr Opin Ophthalmol. 2006;17(5):471-479. doi:10.1097/01.icu.000024 3021.20499.4b

5. Sánchez-Carpintero I, Candelas D, Ruiz-Rodríguez R. Dermal fillers: types, indications, and complications. Actas Dermosifiliogr. 2010;101 (5):381-393. doi:10.1016/j.ad.2010.01.004

6. Breithaupt A, Fitzgerald R. Collagen stimulators: poly-L-Lactic acid and calcium hydroxyl apatite. Facial Plast Surg Clin North Am. 2015;23(4):459-469. doi:10.1016/j.fsc.2015.07.007
7. Kontis TC. Contemporary review of injectable facial fillers. JAMA Facial Plast Surg. 2013;15(1):58-64. doi:10.1001/jamafacial.20 13.337

8. Bauer U, Graivier MH. Optimizing injectable poly-L-lactic acid administration for soft tissue augmentation: the rationale for three treatment sessions. Can J Plast Surg. 2011;19(3):e22-e27. doi:10.1177/229255031101900311

9. Boraldi F, Croce MA, Quaglino D, et al. Cell-matrix interactions of in vitro human skin fibroblasts upon addition of hyaluronan. Tissue Cell. 2003;35(1):37-45. doi:10.1016/S0040-8166(02)00101-5

10. Bartus C, William Hanke C, Daro-Kaftan E. A decade of experience with injectable poly-L-lactic acid: a focus on safety. Dermatol Surg. 2013;39(5):698-705. doi:10.1111/dsu.12128

11. Jäger C, Brenner C, Habicht J, Wallich R. Bioactive reagents used in mesotherapy for skin rejuvenation in vivo induce diverse physiological processes in human skin fibroblasts in vitro- a pilot study. Exp Dermatol. 2012;21(1):72-75. doi:10.1111/j.1600-0625. 2011.01400.x

12. Huschtscha LI, Napier CE, Noble JR, et al. Enhanced isolation of fibroblasts from human skin explants. Biotechniques. 2012;53 (4):239-244. doi:10.2144/0000113939

13. Almeida MM, Nani EP, Teixeira LN, et al. Strontium ranelate increases osteoblast activity. Tissue Cell. 2016;48(3):183-188. doi:10.1016/j.tice.2016.03.009

14. Wang QS, Cui YL, Gao LN, Guo Y, Li RX, Zhang XZ. Reduction of the pro-inflammatory response by tetrandrine-loading poly (L-lactic acid) films in vitro and in vivo. J Biomed Mater Res A. 2014;102 (11):4098-4107. doi:10.1002/jbm.a.35083

15. Niiyama H, Kuroyanagi Y. Development of novel wound dressing composed of hyaluronic acid and collagen sponge containing epidermal growth factor and vitamin C derivative. J Artif Organs. 2014;17 (1):81-87. doi:10.1007/s10047-013-0737-x

16. Röck K, Fischer K, Fischer JW. Hyaluronan used for intradermal injections is incorporated into the pericellular matrix and promotes proliferation in human skin fibroblasts in vitro. Dermatology. 2010;221(3):219-228. doi:10.1159/000318905

17. Funt D, Pavicic T. Dermal fillers in aesthetics: an overview of adverse events and treatment approaches. Clin Cosmet Investig Dermatol. 2013;6:295-316. 
18. da Jeremias TS, Machado RG, Visoni SB, Pereima MJ, Leonardi DF, Trentin AG. Dermal substitutes support the growth of human skin-derived mesenchymal stromal cells: potential tool for skin regeneration. PLoS One. 2014;26(9):e89542. doi:10.1371/journal. pone.0089542

19. Paliwal S, Fagien S, Sun X, et al. Skin extracellular matrix stimulation following injection of a hyaluronic acid-based dermal filler in a rat model. Plast Reconstr Surg. 2014;134(6):1224-1233. doi:10.1097/PRS.0000000000000753

20. Yoneda M, Yamagata M, Suzuki S, Kimata K. Hyaluronic acid modulates proliferation of mouse dermal fibroblasts in culture. J Cell Sci. 1988;90:265-273.

21. Butterwick K, Lowe NJ. Injectable poly-L-lactic acid for cosmetic enhancement: learning from the European experience. $\mathrm{J} \mathrm{Am} \mathrm{Acad}$ Dermatol. 2009;61(2):281-293. doi:10.1016/j.jaad.2008.11.881

22. Tsuji H. Poly(lactic acid) stereocomplexes: A decade of progress. Adv Drug Deliv Rev. 2016;15(107):97-135. doi:10.1016/j.addr.20 16.04.017

23. Lombardi T, Samson J, Plantier F, Husson C, Küffer R. Orofacial granulomas after injection of cosmetic fillers. Histopathologic and clinical study of 11 cases. J Oral Pathol Med. 2004;33(2):115-120. doi:10.1111/j.1600-0714.2004.00194.x
24. Engelhard P, Humble G, Mest D. Safety of Sculptra: a review of clinical trial data. J Cosmet Laser Ther. 2005;7(3-4):201-205. doi:10.1080/14764170500451404

25. Ganceviciene R, Liakou AI, Theodoridis A, Makrantonaki E, Zouboulis CC. Skin anti-aging strategies. Dermatoendocrinol. 2012;4(3):308-319. doi:10.4161/derm.22804

26. Gogolewski S, Jovanovic M, Perren SM, Dillon JG, Hughes MK. Tissue response and in vivo degradation of selected polyhydroxyacids: polylactides (PLA), poly(3-hydroxybutyrate) (PHB), and poly (3-hydroxybutyrate-co-3-hydroxyvalerate) (PHB/VA). J Biomed Mater Res. 1993;27(9):11. doi:10.1002/jbm.820270904

27. Kwon TR, Han SW, Yeo IK, et al. Biostimulatory effects of polydioxanone, poly-d, 1 lactic acid, and polycaprolactone fillers in mouse model. J Cosmet Dermatol. 2019;18(4):1002-1008. doi:10.1111/ jocd. 12950

\section{Publish your work in this journal}

Clinical, Cosmetic and Investigational Dermatology is an international, peer-reviewed, open access, online journal that focuses on the latest clinical and experimental research in all aspects of skin disease and cosmetic interventions. This journal is indexed on CAS.
The manuscript management system is completely online and includes a very quick and fair peer-review system, which is all easy to use. Visit http://www.dovepress.com/testimonials.php to read real quotes from published authors. 